\title{
Archaeological Testing of Site 41CC233 Concho County, Texas
}

Wayne C. Young

Follow this and additional works at: https://scholarworks.sfasu.edu/ita

Part of the American Material Culture Commons, Archaeological Anthropology Commons, Environmental Studies Commons, Other American Studies Commons, Other Arts and Humanities Commons, Other History of Art, Architecture, and Archaeology Commons, and the United States History Commons

Tell us how this article helped you.

This Article is brought to you for free and open access by the Center for Regional Heritage Research at SFA ScholarWorks. It has been accepted for inclusion in Index of Texas Archaeology: Open Access Gray Literature from the Lone Star State by an authorized editor of SFA ScholarWorks. For more information, please contact cdsscholarworks@sfasu.edu. 


\section{Archaeological Testing of Site 41CC233 Concho County, Texas}

\section{Licensing Statement}

This is a work produced for the Texas Department of Transportation (TxDOT) by the report producer. TxDOT and the report producer jointly own all rights, title, and interest in and to all intellectual property developed under TXDOT's contract with the report producer. The report may be cited and brief passages from this publication may be reproduced without permission provided that credit is given to both TxDOT and the report producer. Permission to reprint an entire chapter, section, figures or tables must be obtained in advance from either the Supervisor of the Archeological Studies Branch, Environmental Affairs Division, Texas Department of Transportation, 125 East 11th Street, Austin, Texas, 78701 or from the report producer 
AROHAFOLOGICAL TESTING OF SITE $41 \mathrm{CC233}$

CONCHO COUNIY, TEXAS

\author{
Wayne $\stackrel{\text { B y }}{\text { C. Young }}$
}

Texas

State Department of Highways and Public Transportation Highway Design Division

August 1985 


\section{ABSTRACT}

Prehistoric archaeological Site $41 \mathrm{CC} 233$ consists of a burned rock midden and a light lithic scatter outside the right-of-way of US 87 in Concho County, Texas. Testing within the right-of-way was undertaken to determine if the site did extend into the right-of-way area, to determine eligibility for inclusion within the National Register of Historic Places, and to determine site depth and archaeological significance. Recovered evidence suggests that the site minimally extends into the right-of-way and that at least one feature was within the right-of-way. Additional investigations are not warranted due to low recovery rates and construction plans which will effectively cover and protect the portions of the site within the right-of-way. 


\section{INIRODUCTION}

Archaeological Site 41CC233 was recorded at the Texas Archeological Research Laboratory of the Balcones Research Center, The University of Texas at Austin, during 1981. The site was discovered and reported by Daymond Crawford of the State Department of Highways and Public Transportation (SDHPT) cultural resources staff during an archaeological survey of US 87 from $16 \mathrm{miles}$ west of Eden to the Tom Green County line. The site was reported as a small ring midden or burned rock midden with some flint flakes scattered around the midden area. The site was thought to lie outside the right-of-way, but testing was recommended to determine if any of the site might 1 ie subsurface within the right-of-way.

Testing of portions of Site 41CC233 was performed from February 12-15, 1985, in accordance with Procedures for the Protection of Historic and Cultural Properties (36 CFR, Part 800). Wayne C. Young of the SDHPT cultural resources staff conducted the testing, with assistance from the SDHPT District 7 residency in Junction.

Test objectives were to determine if any subsurface portions of the site extended into the right-of-way and to determine site depth, archaeological significance, and the age of the cultural materials at the site. Testing operations were carried out under the auspices of Procedures for the

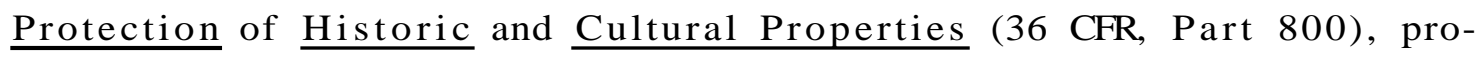
cedures prescribed and endorsed by the Federal Highway Administration. 


\section{SITE DESCRIPTION}

Archaeological Site 41CC233 is located in western Concho County along the south bank of Kickapoo Creek (Fig. 1). The visible portion of the site is located about 100 meters downstream from the intersection of US 87 and Kickapoo Creek and occupies an eroded first terrace which is slightly above the active floodplain of the creek. The abundant flooddrift material within the immediate site area suggests that the creek does flood but that the site itself is above the normal flood level. Major flooding does occur along the lower north side of the present creek channel.

The site consists of a small burned rock midden, or possibly a ring midden, located along a small knoll about 20 meters outside the rightof-way (Fig. 1). Both the north and south margins of the midden area have been heavily eroded to a depth approaching 2 meters, and some of the site has probably been destroyed. Surface examinations of the midden suggest that it originally may have been 15 meters in diameter with a probable depth of 60 to $70 \mathrm{~cm}$. (Depth is approximated as the midden lies outside SDHPT jurisdiction and could not be tested.)

Angular limestone fragments are the principal component of the burned rock midden. Flakes of a low-grade local chert are also visible on the midden surface but appear in low frequencies. Neither chipped nor ground stone tools were observed on or around the midden. The midden supports a profuse growth of prickly pear and tasajillo, and these plants greatly hindered a determination of whether the midden was a Central Texas type burned rock midden or a ring midden.

A surface examination of the site within and outside the right-of-way indicated a very thin lithic scatter around the north, west and south sides of the midden. The east side is the Kickapoo Creek channel and obviously was void of cultural materials. The maximum extent of the site is thought to be 40 meters along the creek and about 10 meters back from 
This Page Redacted Per THC Policy 
the creek. Surface indications are that the site does not extend to the base of the hill 30 meters southeast of the midden. There may be materials buried near the hill by colluvial slope wash.

Vegetation on the site consists of mesquite, prickly pear, yucca, tasajillo, and sparse native grasses. The mesquites are noticeably smaller than those across the creek and may indicate that the area has been chained and root-plowed in the past to eradicate this species. The large number of dead trees and specimens with secondary growth from the roots suggests that these trees have been sprayed in recent years. Ground cover is sparse on and near the site and is the product of overgrazing by sheep.

Erosion is evident across the site and is at least partially attributable to overgrazing by livestock. The soils are brown sands with some caliche gravels and were observed to be readily transportable by the frequent winds in the area. Gullies are also common in the immediate area forming rivulets between the hill and Kickapoo Creek.

Cultural materials within the right-of-way are sparse and consist of widely scattered flakes and an occasional burned rock. Cultural evidence is most common on and immediately adjacent to the burned rock midden outside the right-of-way. This evidence consists of burned rock and flint flakes. 


\section{TESTING PROCEDURES}

Archaeological testing of portions of Site $41 \mathrm{CC} 233$ within the SDHPT project right-of-way consisted of two contiguous 1 by 1 meter squares and a separate 1 meter square (Fig. 2). All were excavated with shovels and trowels in arbitrary 10 om vertical levels from the existing ground surface. Soil was passed through $0.25 \mathrm{in}$. mesh hardware cloth and all recovered cultural material was bagged and labeled by unit and level. These materials were brought to the SDHPT Laboratory for Archaeological Studies for analysis and temporary storage.

Test units were placed on the outside edge of the right-of-way near the burned rock midden between Highway Stations 179 and 181. Test Unit 1, the isolated 1 meter square, was located nearest the midden and was excavated to a depth of 5 meters. The contiguous 1 by 1 meter units (Test Units 2 and 3) were excavated to a depth of $40 \mathrm{~cm}$. Test Unit 2 was originally excavated to $40 \mathrm{~m}$ where a hearth was encountered. Test Unit 3 was situated on the south side of Test Unit 2 and was excavated to expose more of the feature. 



\section{OBSERVATIONS}

A total of 83 flint flakes and 1 limestone hearth was uncovered during the testing of Site 41CC233. A total of 13 levels was excavated. Nb bone, diagnostic artifacts, tools, or snails were detected subsurface or on the surface within the right-of-way. A Nolan dart point was found downstream from the site but cannot be directly associated with the site. Flake densities from the excavated levels and units are presented in Table 1.

TABLE 1. Flake densities from excavated units.

\begin{tabular}{c|c|c|c}
\hline Level & Test Unit 1 & Test Unit 2 & Test Unit 3 \\
\hline 1 & 26 & 16 & 23 \\
2 & 6 & 0 & 3 \\
3 & 3 & 3 & 3 \\
4 & 1 & 0 & 0 \\
5 & 0 & & \\
\hline \hline
\end{tabular}

The data from Table 1 show that the majority of cultural debitage at Site 41CC233 is located within the upper 10 om of the site deposits. Feature 1 was located in Levels 3 and 4 of Test Units 2 and 3. These levels contained only 6 flakes with none in direct association with the feature.

Feature 1 was a partially exposed limestone hearth. It measured $\mathbf{1 . 1 0}$ meters at its widest and a circular shape was suggested. This feature was basin-shaped and was composed of two layers of burned limestone rock fragments. Charcoal, bone, tools, and flakes were found to be lacking within this feature. 


\section{CONCUSIONS AND RBCOMMENDATIONS}

Archaeological testing within the right-of-way at Site 41CC233 has indicated that some portions of the site do extend into the rightof-way of US 87. The majority of the cultural deposits are outside the highway $1 \mathrm{imits}$ and occur either on or immediately adjacent to the burned rock midden. While at least one intact feature occurred within the right-of-way, the site appears to have a very low density occupation in the right-of-way area. Construction plans call for construction of an embankment over the site area in the right-of-way, with 4 to $17 \mathrm{ft}$. of $\mathrm{fi} 11$ being deposited. This activity should lead to no adverse affect on the site area within the right-of-way. It is believed that the portions of Site 41CC233 within the right-of-way do not meet the criteria for inclusion within the National Register of Historic Places. 